\title{
L'Association des Ecrivains de Langue Française
}

L'ADELF (Association des Écrivains de Langue Française) a décerné le 2i Novembre son Grand Prix Littéraire de l'Afrique Noire à Guy Menga du Service de l'Information du Congo-Brazzaville pour son roman La Palabre Stérile. Rappelons que parmi les Prix Littéraires décernés par l'ADELF figurent notamment le Prix de Madagascar (dernier lauréat le Père de Méritens pour Le Livre de la sagesse malgache) et le Prix des Mascareignes (dernier lauréat Auguste Toussaint, Conservateur des Archives de Maurice pour l'ensemble de son œuvre). L'ADELF (38, rue du Faubourg Saint-Jacques, Paris XIVe) qui regroupe quelques 600 écrivains dont une centaine originaires d'Afrique et de Madagascar, a pour organe la revue Culture Frangaise (Abonnement Annuel $20 \mathrm{~F}$ ).

\section{Standardization of African Proper Names}

THE Department of History of the University College of Rhodesia, in consultation with the Department of African Languages, is working on a proposed standardization of proper names for use in Central African History, with listings of some variants used by earlier writers with little or no knowledge of the African languages concerned. Lists can be obtained on request from Mr. P. R. Warhurst.

\section{NOTES FOR CONTRIBUTORS TO $A F R I C A$}

Contributions should be addressed to the Editor. Articles should not exceed 8,000 words, including footnotes and references. Longer papers can be accepted in exceptional circumstances if a subsidy can be provided to meet the cost of printing additional pages.

Articles should be typed in double spacing, on one side of the paper only, with ample margins to allow for editorial marking. Clean copy ready for printing should be provided. Authors are advised to keep a copy of their texts as the return cannot be guaranteed. Words in African languages should be underlined and special characters kept to a minimum. Footnotes may be placed at the bottom of the page on which they occur or all together at the end. Bibliographical references should be cited only briefly (i.e. author and date) in the text or in footnotes, and an alphabetical list of references given in full at the end of the article. Where appropriate the text should be divided by suitable headings and sub-headings. Tables outside the text should be typed on separate pages, numbered consecutively and given headings. Maps and other line drawings should be submitted in final form (except for size) on good-quality paper.

Contributors are asked to provide a summary of their articles of 250-300 words for translation into French or English.

Galley proofs are submitted to authors but only essential corrections can be accepted; additional matter cannot be inserted at proof stage. The Editor reserves the right to make any corrections or alterations he may deem necessary.

Contributors receive 25 free offprints of their articles; extra copies can be supplied at cost price on request, if ordered before publication. 